\title{
SOCIAL ACTOR REPRESENTATION ANALYSIS ON THE JAKARTA POST ONLINE NEWS OF PRESIDENTIAL ELECTION
}

\author{
Nuri Hidayatus Sholihah ${ }^{1}$ and Agwin Degaf ${ }^{2}$ \\ (nurihidayatus21@gmailcom) \\ 1. Universitas Islam Negeri Maulana Malik Ibrahim Malang \\ ${ }^{2}$.Universitas Islam Negeri Maulana Malik Ibrahim Malang
}

\begin{tabular}{ll}
\hline ARTICLE & ABSTRACT \\
\cline { 2 - 2 } Keywords: & $\begin{array}{l}\text { Social actor representation (SAR) is an interesting topic to be analyzed. } \\
\text { Through the analysis of the social actor in the news, it invites readers to have } \\
\text { critical thinking. In this research, the social actors proposed are the two pair } \\
\text { candidates of the } 2019 \text { presidential election; Jokowi- Ma'ruf and Prabowo- } \\
\text { Representation, }\end{array}$ \\
Sandi. The research has consisted of two research questions. First is, how are \\
the exclusion strategy used in the Jakarta Post online news to represent the \\
online news
\end{tabular} $\begin{aligned} & \text { social actor. Second is how are the inclusion strategy used in the Jakarta Post } \\
& \text { online news to represent the social actor. By using the theory of Van Leeuwen } \\
& \text { (2008), the result of this research shows that the journalist of the Jakarta Post } \\
& \text { mostly used inclusion strategy rather than the exclusion strategy.The } \\
& \text { identification strategy is mostly used to get support from the public. The } \\
& \text { identification is practical in figuring out and portraying a social actor. } \\
& \text { Journalists represent related to the identity that exists in a figure. The portrayal } \\
& \text { of the social actors through the identity attached to them can certainly invite } \\
& \text { more attention to readers. }\end{aligned}$

\section{INTRODUCTION}

Indonesia has an event that is held every five years, called the presidential election. This year, the presidential election held on April $17^{\text {th }}, 2019$. The presidential election is a medium to conduct sovereignty in Indonesia. The presidential election aims are to give democracy country, in which the leaders are based on the majority of populace voices. At the time of the election, there are many discourses turned up about the presidential candidates. Therefore, the presidential election moment is a controversial situationwith any issues that always discussed. The issues can occur in any resources such as television programs, social media, print newspapers, and also online news. From this situation, the researchers chose to do analyzing the social actor representation through media coverage. The media coverage here means in online news that is the Jakarta Post online. 
The Jakarta Post is one of the Indonesian media written in the English language. It was reported about Indonesia's country and also international issues.The Jakarta Post also owns the political news content. Therefore, the researcher found the online news texts from the Jakarta Post online news as the data. For this study, the researchers took news text in the Jakarta Post start on January $18^{\text {th }}, 2019$, up to February $16^{\text {th }}, 2019$. The date was after the debate, until close the second president's debate that is held on February $17^{\text {th }}, 2019$. The appointed time was the appropriate time to be filtering the news. It is the time that has the influence is getting debatable news after the first round of debate. Moreover, there are some events that make controversial issues during the first debate. Therefore, it becomes a unique issue that interest to be analyzed. From the collected data during one month above, the researcher analyzed the data with a discourse analysis (DA) approach.

Discourse analysis can be useful in many fields that focused on communication, sociology, psychology, or anthropology. Discourse analysis is an approach concerning social relations like dominance and solidarity. Discourse analysis is the difference from critical discourse analysis, which regarded the use of language in speech and written text as a social practice (Fairclough and Wodak, 1997). A critical discourse analysis influenced the dialectical relation between a discursive event with the situation, institution, and social structure. Critical discourse analysis sees the language as an essential factor, how the language used to see the social lameness. For this research, the discourse analysis approach used to investigate the discourses in the news article.

In this research, the researchers used the discourse analysis approach through the theory proposed by Van Leeuwen (2008) to analyze the data. Social actor representation (SAR) by Theo Van Leeuwen is the theory for understanding how the group or people marginal their position in discourse. Social actors are significant because social actors are important to be analyzed in discourse (Koller, 2009). The social actor in this research means the two pair candidates; JokowiMa'ruf and Prabowo- Sandi. In Van Leeuwen's theory, there are two kinds of categories used to analyze how the social actors represented. The two categories are exclusion and inclusion. In exclusion, there are groups or social actors that have been eliminated from the news. In inclusion, the inclusion is to analyze how social actors are shown in a report. Both exclusion and inclusion, there are distinguished into several categories as the strategy to analyze the discourses.

Therefore, this research has two objectives, first, to describe the way social actors represented in the Jakarta post online news by the exclusion strategy. Second is to describe the way social actors represented in the Jakarta Post online news by the inclusion strategy. 


\section{METHOD}

The data for this research is a form of words, clauses, phrases, and sentences. The researchers found 12 data of news text in the Jakarta post online news. Those twenty-two texts are found after the first debate up to before the second debate. The data sources of this research are the news text after the first round of candidate debate on the Jakarta post online. The researcher analyzed how the social actor has shown based on the theory used. The researcher found the news that used as the data source from the link www.thejakartapost.combecause this is an official link which trusted as the source.

The researchers collected the data in several steps. Firstly, the researchers found the data sources- the data collected from the internet. Secondly, data is selected from the news texts on the Jakarta post online. In this part, the news text took from January $17^{\text {th }}$ until February $16^{\text {th }}$, which is the time after the first debate of the candidate. The last, the data are arranged systematically in the following research focus. The researcher analyzed the data by using a discourse analysis approach. The researchers analyzed the existing data through several steps. First, the researchers used the aggregate data from the Jakarta Post online news in the specified time. Second, the researchers categorized the data appropriate based on the theory proposed by Van Leeuwen (2008). The researchers took the collecting data into a table of findings in order to make it easier for analysis. The data were consists of exclusion and inclusion strategy. Exclusion strategies consists of, passivation and nominalization. Inclusionstrategies consists of, differentiation-indifferentiation, genericization-specification, nomination-categorization, functionalization-identification, assimilation- individualization, and association- dissociation. Third, the researchers explained how the strategies used in the text based on the table of findings. Fourth, the researchers discussed the result of the research. The last, the researchers made a conclusion based on the result of answering this research objective.

\section{FINDINGS AND DISCUSSION}

According to data analysis, the researchers found two strategies used in representing the social actor as Van Leeuwen theory; exclusion and inclusion strategy. Based on the result of the analysis, the use of inclusion strategy has several purposes, such as for marginalizing a particular group, stereotype an issue, differentiate a social actor with other, to show who is dominant in a particular group or country. Related to the theory, both the inclusion and exclusion strategy is used in this research. 


\section{A. Exclusion}

Exclusion strategy is an essential strategy in discourse analysis (Van Leeuwen, 2008). Usually, exclusion leaves no traces in the representation, excluding both the social actor and their activities. Exclusion strategy consists of two-part; those are passivation and nominalization. Based on the findings, the researcher describes the data, which includes into exclusion strategy.

\section{Passivation}

In this study, the journalist of Jakarta Post uses passivation to hidden the social actor because the most important to report is the object, not the subject. There are about two cases of passivation cases contained in the text used in the Jakarta Post with a different article. The article10 entitled "Jokowi plays it tough, accusing Prabowo of 'outbursts of lies'" was published on Monday, February 4, 2019. The article was concerned about the opposition of Jokowi to Prabowo. The journalist of Jakarta Post almost uses a passivation strategy in their news to exclude social actors from a text. The function of passivation is to include the actor in part of the sentence. In this study, the writer considered to explain the actor's actions clearly and explain the action without a clear actor. For example:

\begin{tabular}{|l|l|}
\hline Passivation & $\begin{array}{c}\text { The anniversary event was held concurrently with a declaration of } \\
\text { support for the incumbent by a group of volunteers. (Article } \\
10)\end{array}$ \\
\hline Activation & $\begin{array}{c}\text { A group of volunteers held the anniversary event with a } \\
\text { declaration of support for the incumbent. }\end{array}$ \\
\hline
\end{tabular}

The article above was discussing declaration support to Jokowi by volunteers. There was focused on something happened, here concerning to anniversary event held by volunteers. The focus is on the processes or something that happened rather than on the people carrying them out. The social actor was excluded from the text, although it was reported about Jokowi, implicitly. While in the activation strategy, the subject is needed, then there is a verb located after the subject.

\section{B. Inclusion}

The inclusion and exclusion strategy has a different way to present a social actor. In exclusion, the social actor was excluded through passivation and nominalization. It is hardly 
different from inclusion. Inclusion is represented as the social actor in particular action. The several strategies used in the Jakarta Post online news will explain in the following subchapter.

1) Activation

First, the inclusion strategy used in the Jakarta Post in reporting the social actor is activation. The representation of the use of activation and passivation strategy is the opposite. When the activation strategy is used, the social actor could be included in the text. The article-2 entitled "Seven key moments in the first presidential debate," was published on Friday $18^{\text {th }}, 2019$. Like the title, this article has seven points that discussed the moments that happen in the first presidential debate. For the activation strategy, the researchers found an example that exists in the second article. Here the sentence indicates as activation strategy:

\begin{tabular}{|l|l|}
\hline Activation & $\begin{array}{c}\text { Joko "Jokowi" Widodo ended the first presidential election debate on } \\
\text { Thursday night with a strong closing statement that appeared to } \\
\text { slam rival PrabowoSubianto, whom himself made a number of } \\
\text { controversial remarks during the event. (Article 2) }\end{array}$ \\
\hline Passivation & $\begin{array}{l}\text { The first presidential election debate on Thursday night was ended by } \\
\text { Joko "Jokowi" Widodo with a strong closing statement that } \\
\text { appeared to slam rival PrabowoSubianto, whom himself made a } \\
\text { number of controversial remarks during the event. }\end{array}$ \\
\hline
\end{tabular}

The sentence above indicates as an activation strategy because the social actor is represented as the social actor (Jokowi) who does the action. There is subject (Joko Widodo) who as doer from the verb. Then, the word "ended" as a verb is located after the subject. Here, activation is a strategy to include the social actor in the text. It is not the same as passivation, which excluded the social actor from the text.

\section{2) Differentiation- Indifferentiation}

Secondly, besides the exclusion strategy, the discourses in the Jakarta Post also investigated by inclusion strategy. The strategy of inclusion that used in several news articles is differentiation-indifferentiation. The article-12 published on Thursday, February 14, 2019, was "Rival camps gear up for second presidential debate." The news article was about the preparation 
of both candidates for the second presidential debate that holds on the upcoming February 17, 2019.) The social actor can be shown individually as a unique phenomenon, but it also contrasts by showing another figure. The presence of another figure indirectly shows that one group is better than another group. The use of a differentiation strategy could appear the effect on the reader. The text will make the reader to critical thinking between two social actors. The example of a differentiation strategy that used in the article-12 is:

\begin{tabular}{|l|c|}
\hline Differentiation & $\begin{array}{c}\text { The opposition camp, however, often criticized Jokowi's } \\
\text { administration for relying on foreign loans for infrastructure } \\
\text { development across the country, with Prabowo and running } \\
\text { mate Sandiaga Uno promising they would develop } \\
\text { infrastructure without foreign loans. (Article 12) }\end{array}$ \\
\hline
\end{tabular}

In the sentence, the presence of Jokowi's achievement infrastructure exactly gives an occasion to Prabowo's entrenchment to denounce by way of promising that Prabowo creates infrastructure development without foreign loans. The differentiation strategy occurs in prejudice. Mainly it will become a boundary of both social actors. The first social actor is better than the second social actor, or the contrary. Based on Van Leeuwen's thinking, the representation like "differentiation" is a strategy to show how the social actor becomes ostracism or bad.

The article-4 was published on Tuesday, January 22, 2019, with the title "Bawaslu examines tabloid distributed to mosques ahead of elections." This news was discussed about the tabloid distributed to mosques and Islamic boarding.The strategy was used in the article-4 is indifferentiation:

\begin{tabular}{|l|l|}
\hline Indifferentiation & $\begin{array}{l}\text { Obor Rakyat's editors, Setyardi Budiono and Darmawan } \\
\text { Sepriyosa, were imprisoned in December for spreading false } \\
\text { news about Jokowi during } 2014 \text { election campaign. (Article }\end{array}$ \\
& $4)$
\end{tabular}

In the sentence, there is a figure from other institutions that have been spreading false issues about Jokowi in the 2014 general election. The reporter takes another institution 'Obor Rakyat' in order to show that Jokowi is in the right position. Therefore, the news that has been 
spread is false. It is in contrast with the differentiation strategy, which compares both the social actors, one is better than the other one.

\section{3) Genericization-Specification}

Thirdly, the strategy used by the journalist is genericization- specification. For the genericization strategy, there were two cases that investigated as genericization. One of example is in the article-6. "Could nonvoters turn the election?" It was a title of the news about abstaining in the election. This article mentioned that some voters and activists express they are disappointed with both presidential tickets. While the specification, there are about six discourses which used specification strategy. As in the article-11 entitled "Muhammadiyah warns of divided Indonesia ahead of April elections" was published on Wednesday, February 13, 2019. The article was told about Prabowo supporters from the Muhammadiyah coalition. The journalist of the Jakarta Post uses genericization and specification to show how the social actor depicted in the text, whether mentioned by general or specific. As the example, here is the use of genericization strategy:

\begin{tabular}{|l|c|}
\hline Genericization & $\begin{array}{c}\text { Former supporters of Jokowi, in particular, have } \\
\text { expressed their discontent with the incumbent, } \\
\text { especially after the announcement of cleric Ma'ruf } \\
\text { Amin as his running mate last August. (Article 6) }\end{array}$ \\
\hline Specification & $\begin{array}{l}\text { Former minister of finance, Sri Mulyani has expressed } \\
\text { their discontent with the incumbent, especially after } \\
\text { the announcement of cleric Ma'ruf Amin as his } \\
\text { running mate last August. }\end{array}$ \\
\hline
\end{tabular}

In this sentence mentioned that some of the former supporters of Jokowi were declared they are disappointed. Here the journalist just mentioned "former supporters," it means that general. The effect of generalization will increase if the anonymous used in plurality, such as many people, some people, etc. The reader cannot gain whom the person or the specific name intended. The use of "former supporters" were shows plural meaning. It makes difference a perspective to the reader when the former supporter of Jokowi is changing into a clear name of a person, like in the specific table above. The use of "Sri Mulyani" name is more specific than "former supporters" as if all of the former supporters are disappointed to the incumbent. 
The next example is the specification strategy that used in the Jakarta Post online news:

\begin{tabular}{|l|l|}
\hline Specification & $\begin{array}{l}\text { Amien, a supporter of Prabowo in the } 2019 \text { election, has been a } \\
\text { vocal critic of Jokowi, and has been seen as a controversial } \\
\text { figure in Indonesia's political scene, although he is known as an } \\
\text { icon behind } 1998 \text { reform, marking the downfall of Soeharto. } \\
\text { (Article 11) }\end{array}$ \\
\hline Genericization & $\begin{array}{l}\text { A supporter of Prabowo in the } 2019 \text { election, has been a vocal critic } \\
\text { of Jokowi, and has been seen as a controversial figure in } \\
\text { Indonesia's political scene, although he is known as an icon } \\
\text { behind 1998 reform, marking the downfall of Soeharto. }\end{array}$ \\
\hline
\end{tabular}

For reporting the social actor above, the journalist used a specific name. The use of specification strategy in this discourse will appear the reader or societies to have the perspective that Prabowo's supporter was judged as a backbiter, although it was in the past. Both genericization and specification have a different perspective on the reader's influence. When the social actor represented through genericization, it could be anonymous because the figure is not mentioned. For any reason, it has a different impression when received by the public. When the social actor represented by specification, there was mentioned the specific name, and it has a singular meaning. The use of specification strategy does not take any questions because it was specific, as an individual.

\section{4) Categorization}

Fourthly, the other strategy used in the news text of the Jakarta Post is nominationcategorization. The nomination can be realized by a proper noun, which can be formal, semiformal, and informal. While categorization realized by unique identity, high status, ordinary people, or occupation. For this research, the researcher found categorization existed in the news text. The article-8 entitled "Will the real millennial please stand up?" was published on Wednesday, January 30, 2019. The article was told about millennial voters this year, which for the total of the electorate is dominated by 17 up to 35 aged voters. There was a text which show that the journalist uses categorization strategy, for example: 


\begin{tabular}{|r|r|}
\hline Categorization & $\begin{array}{r}\text { Running mate Sandiaga Uno, on the other hand, needs no help in } \\
\text { that department, with multiple polls showing that young people } \\
\text { are drawn to his image as a successful businessman. (Article 8) }\end{array}$ \\
\hline
\end{tabular}

Through the categorization, the social actor can be represented by the term of unique identity, high status, ordinary people, or occupation. The reporter was provided Sandiaga Uno as a businessman. By mentioned, Sandi is a businessman; it will invite public interest for the vice president of Prabowo, especially the young and the woman. In the time of the campaign, PrabowoSandi also performed in their campaign. Prabowo has been striving to project a more laid back public persona to interest millennial voters.

\section{5) Identification}

Fifth, the strategy that has used in the Jakarta Post online news is categorized as functionalization- identification. Both functionalization and identification, it was just identification that used in the text. Eight texts have been used identification strategy. The identification itself has three various types. The first is the type of classification, and the second is relational identification, it could be proofed by possessive or belonging together such "my daughter/ my mother." The third is physical identification. The types of identification used in eight texts are included in the classification type. The article-10, entitled "Jokowi plays it tough, accusing Prabowo of 'outbursts of lies'" was published on Monday, February 4, 2019. The article was concerned about the opposition of Jokowi to Prabowo. Jokowi made strong remarks slamming his rival in is speeches about Prabowo's statement that Indonesia could become extinct to accusing the rival camp using foreign consultants. This is an example of the identification strategy from the article-10:

\begin{tabular}{|l|l|}
\hline Identification & $\begin{array}{c}\text { Donning a white shirt, white scarf, traditional black peci, } \\
\text { andhissarong, Ma'ruf soon became the talk of the town. (Article- } \\
10)\end{array}$ \\
\hline
\end{tabular}

Through the classification type, the social actors could be represented their differences among the class of people, age, gender, provenance, class, wealth, race-ethnicity, religion, and sexual orientation. The effect of showing the social actor through this strategy is to influence the reader thinking about the social actor by unpretentious. Sarong and peci is become the identity of Ma'ruf Amin, it shows his religiosity. As a vice-president, Ma'ruf Amin with his identity naturally becomes an effort to the interest of public, especially Islam people. Moreover, here is the country 
that has the most prominent adherent of Islam, so Ma'ruf Amin figure will get much supports, especially from Islam.

\section{6) Association}

Sixth, the last strategy used in the news text is association- disassociation. Association is a way that the social actor can be represented as a group. It refers to a group which formed by social actor or group of the social actor. In this strategy, the social actor always related to other groups. The article-7 entitled "Prabowo will not create an Islamic caliphate, says Christian brother" was published on Monday, January 28, 2019. It was told about the issue of whether Prabowo will create an Islamic caliphate or not if he won in the upcoming election. There were two texts which categorized in the association. One of the two texts that identified as association strategy is:

\begin{tabular}{|l|l|}
\hline Association & $\begin{array}{c}\text { Prabowo's support among conservative Muslims, including former } \\
\text { symphatizer of the now-banned HizbutTahrir Indonesia (HTI), } \\
\text { has led to rumors that he would turn Indonesia into an Islam- } \\
\text { based state if he was elected. (Article 7) }\end{array}$ \\
\hline Dissociation & $\begin{array}{l}\text { Prabowo's support among conservative Muslims symphatizer has } \\
\text { led to rumors that he would turn Indonesia into an Islam-based } \\
\text { state if he was elected. }\end{array}$ \\
\hline
\end{tabular}

The social actor here (Prabowo) was related to other institutions or social groups. The existing of HizbutTahrir Indonesia in the sentence makes the reader think that Prabowo is a part of HTI. As we know that HTI is a controversial group with the contrary assumption. HTI, in this case, shows where the social actor (Prabowo) exist is. Association shows a particular group related to the social actor, but the problem is whether the group mentioned explicitly or not. If the group is not mentioned explicitly, it becomes disassociation, like in the example above.

The findings of this research show that the journalist of the Jakarta Post mostly used inclusion strategy rather than an exclusion strategy. The identification strategy is often used in the texts. Based on the term of identification, this strategy mostly used is because it can easily create a unique figure of the social actor. It also makes the public interest in the social actors, especially to 
vote them. Therefore, the journalist of the Jakarta Post online is often used the identification strategy, which becomes an effective way to look for the support of the public.

\section{CONCLUSION AND SUGGESTION}

Based on the findings, the researchers proposed several conclusions. First, in reporting the news, the journalist of the Jakarta Post online news adopted the exclusion and inclusion strategy. The exclusion strategy is consists of passivation as the way to hidden the social actor because the most important to report is the object, not the subject. Second, the inclusion strategy is mostly used in reporting the social actor. The use of inclusion strategy is consist of some types, are differentiation- indifferentiation, genericization- specification, nomination- categorization, functionalization- identification, and association- disassociation. In this research, there was a news article that used two strategies, exclusion and inclusion. It occurs in the last news article. The last news article consists of a passivation strategy (included in the exclusion) and differentiation strategy (included in the inclusion).

Firstly, the strategy used by the journalist of the Jakarta Post is exclusion. In the part of exclusion, the researcher found a passivation strategy used to represent the social actor. There are two cases in the use of the passivation strategy. The purpose of the passivation strategy is to exclude the social actor from the text. It occurs because the object is more important to be focused, rather than subject. Passivation is a process of how the social actor not involved in the text. Excluded social actor aim to protect themselves.

Secondly, the strategy used by the Jakarta Post is an inclusion strategy. The most strategy used in the news article is identification. The identification strategy is covering a unique figure of the social actor. From the use of identification, it is influencing the reader or the public to more interest in the social actors. The use of identification strategy is to hold the sympathy from the public. The Jakarta Post online news mostly used identification strategy because the identification strategy became an effective way to get public support. Besides, identification is practical in figuring out and portraying a social actor. Journalists represent related to the identity that exists in a figure. The portrayal of the social actors through the identity attached to them can certainly invite more attention to the reader. For example, when Amin was reported to be on the stage of the presidential debate by wearing sarong and cap, it was a religious depiction of Ma'ruf Amin.

In this case, the identification strategy is often used because this is a way that closes to get the reader's interest. The journalist represented a social actor using an identity such as a class of 
people, age, gender, provenance, class, wealth, race-ethnicity, or religion, which attached to the social actor. The reader more easily accepts this way because, in reporting, the social actors can not be separated from the identity attached to them.

The researchers proposed several suggestions for the reader and the next researchers who will research the same topic. The analysis of social actor representation on the Jakarta Post online news is providing to the reader as the understanding base of discourse analysis. First, the research is suggested to the reader in order to more have critical awareness in reading and receiving the news. In this research, the reader expected to differentiate the meaning of the use of exclusion and inclusion strategy. The use of exclusion strategy, for instance, passivation, it means that the journalist wants to hide the social actor. The social actor excluded from the text because of the passive sentence. Also, the use of inclusion strategy, in this case, the dominant strategy used in the text, was the identification strategy. The use of identification strategy tended to portray the social actor because it becomes an interesting way to reach public interest.

Second, for the next researcher who will conduct the same topic of discourse, it is preferable to use another theory of discourse. It is because the theory of Van Leeuwen too focused on the text-only. The next researcher can look for another theory that can see another particular side to analyze the discourse. Even the use of other theories of discourse analysis is better to get the result more objective. Besides, the next researcher better if using printed newspapers because online newspapers are more prioritize the quantity rather than quality. Evensome texts that have mistakes or grammatical errors. The printed newspaper is more prioritize the quality of the writing process than online news. Therefore, the researcher suggested that the printed newspaper is better to do analyze.

\section{REFERENCES}

Abdullah, R. (2009). Mewujudkan pemilu yang lebih berkualitas. Jakarta: Grafindom Persada.

Assyari, A. (2017).Membaca komunikasi politik gerakan aksi bela islam 212: antara politik identitas dan ijtihad politik alternatif. JurnalAnnida'. Vol 41.2.

Cheng, J.E. Anti- racist discourse on muslims in the Australian parliament. Benjamin publishing company. Australia.

Cresswell, John W. (1997). Research design: qualitative, quantitative, and mixed methods approaches. Los Angeles: Sage Publishing.

Dominick, J.R. (2005).The dynamics of mass communications.Media in the digital age. United States. 
Davari, S \&Moini, M. R. (2016).The representation of social actors in top notch textbook series: a critical discourse perspective. Vol 4.13.69-82.2016

Duleimi, A. D. A \&Ebadi, H K A.2016.Ideology in news report: Al- Jazeera reporters as representative: a critical discourse analysis. Vol 4.2: 53-66. 2016

Eastwood, J. (2008). Oxford learner's pocket grammar. New York: Oxfords University Press.

Eriyanto.(2009).Analisis Wacana Pengantar Analisi Teks Media.PT. LKis Printing Cemerlang. Bantul, Yogyakarta

Fairclough, N and R. Wodak. (1997). Critical discourse analysis: a multidisciplinary introduction, ed. By Teun A. Van Dijk.Vol 2. London: Sage.

Halliday, M.A.K. (1985).An Introduction to Functional Grammar, London: Arnold.

Koller, V. (2009). Analyser une identite collective en discours: Acteurs sociaux et contexte et d'acteurs sociaux. Besangon cedex: France press university.

Leeuwen, Theo Van. (2008). “Discourse and Practice.”New Tools for Critical Discourse Analysis. New York: Oxford University Press.

Nyhan, B and Sides, J. (2011). How political science can help journalism (and still let journalists be journalists), Vol .9.

Official website of the Jakarta Post online news, www.thejakartapost.com

Qanitat, K (2015). Social Actor Representation on Islamic Issues in The New York Times and The Guardian Newspapers. Unpublished Thesis. Malang: Maulana Malik Ibrahim State Islamic University of Malang.

Rahimi, A and Amirian, M.R. (2017).A critical discourse analysis of the representation of Iranians I a western movie not without my daughter.Vol. 3.3.55-71.

Ranchman, A and Yunianti, S. (2017).Critical discourse analysis in donald trump presidential election campaign to win american's hear. Vol.5.2.8-17.

Sukrisno, A. 2010.Discourse analysis on advertisement. Language Circle Journal of Language and Literature IV. Semarang.

Stubbs, M. 1983. Discourse Analysis. Chicago:University Chicago Press.

Thaib, Dahlan. (2009). Ketatanegaraan Indonesia. Perspektif konstitusional.Totalmedia.Yogyakarta.

Ulum, O. G. (2016). Newspaper ideology: a critical discourse analysis of news headlines on Syrian refugees in published newspapers. Vol 11.541-552 Turkey: Ankara.

Van Dijk, T.A. (1997). The Study of Discourse. Van Dijk. In Van Dijk, Teun (Ed) Discourse Studies: A Multidiciplinary Introduction. Vol 1. 